\title{
Carcinoma of the lung in Ontario gold miners: possible aetiological factors
}

\author{
R A Kusiak, J Springer, A C Ritchie, J Muller
}

\begin{abstract}
A cohort of 54128 men who worked in Ontario mines was observed for mortality between 1955 and 1986. Most of these men worked in nickel, gold, or uranium mines; a few worked in silver, iron, lead/zinc, or other ore mines. If mortality that occurred after a man had started to mine uranium was excluded, an excess of carcinoma of the lung was found among the 13603 Ontario gold miners in the study (standardised mortality ratio (SMR) $129,95 \%$ confidence interval (95\% CI) 115-145) and in men who began to mine nickel before 1936 (SMR 141, 95\% CI 105184). The excess mortality from lung cancer in the gold miners was confined to men who began gold mining before 1946. No increase in the mortality from carcinoma of the lung was evident in men who began mining gold after the end of 1945 , in men who began mining nickel after 1936, or in men who mined ores other than gold, nickel, and uranium. In the gold mines each year of employment before the end of 1945 was associated with a 6.5\% increase in mortality from lung cancer 20 or more years after the miner began working the mines (95\% CI 1.6-11.4\%); each year of employment before the end of 1945 in mines in which the host rock contained $0 \cdot 1 \%$ arsenic was associated with a $3 \cdot 1 \%$ increase in lung cancer 20 years or more after exposure began $(95 \% \mathrm{CI}$ $1 \cdot 1-5 \cdot 1 \%)$; and each working level month of exposure to radon decay products was associated with a $1.2 \%$ increase in mortality from lung cancer five or more years after
\end{abstract}

The Health and Safety Studies Unit, Ontario Ministry of Labour, 400 University Avenue, 8th Floor, Toronto, Ontario M7A 1T7, Canada

R A Kusiak, J Muller

Ontario Geological Survey, Ministry of Northern Development and Mines

J Springer

Mount Sinai and Toronto General Hospitals A C Ritchie exposure began (95\% CI $0 \cdot 02-2 \cdot 4 \%)$. A comparison of two models shows that the excess of lung cancer mortality in Ontario gold miners is associated with exposure to high dust concentrations before 1946, with exposure to arsenic before 1946, and with exposure to radon decay products. No association between the increased incidence of carcinoma of the lung in Ontario gold miners and exposure to mineral fibre could be detected. It is concluded that the excess of carcinoma of the lung in Ontario gold miners is probably due to exposure to arsenic and radon decay products.

Earlier reports have shown that the incidence of carcinoma of the lung is increased in miners who worked in Ontario gold mines before 1945. ${ }^{12}$ The? cause of the increase was not established, although it was noted that these men were exposed to radon decay products, silica, arsenic, and mineral fibre. Radon decay products have been shown to increase mortality from lung cancer in several mining populations. ${ }^{3}$ Some reports have suggested that exposure to arsenic in underground mines is associated with an excess of lung cancer ${ }^{45}$ and some suspect that silica dust is carcinogenic in the lungs. ${ }^{6}$ The earlier report ${ }^{2}$ suggested that exposure to arsenic in the Ontario gold mines was associated with the excess of mortality from lung cancer, but at that time little was known about exposure of the miners to radon decay products.

This study extends the end of the period of observation of the cohort of miners studied earlier from 1977 to the end of 1986 . The longer period of follow up is used to examine whether an excess of carcinoma of the lung exists in Ontario gold miners who began work in the mines after 1945. It also allows us to reconsider the role of radon decay products, arsenic, and mineral fibre using data from a survey of the concentrations of radon decay products in many Ontario gold mines that are now available, data about the arsenic content of mine tailings and rock samples taken from Ontario gold mines, ${ }^{7}$ and geological information about the presence of mineral fibre in gold mines. 


\section{Materials and methods}

\section{ASSEMBLING THE COHORT OF MINERS}

Since 1928 each miner working in Ontario has been required to be examined once a year by a physician at a provincially operated chest clinic for certification as being fit to continue working in jobs with dust exposure in the mining industry. At these examinations the miner reports details about his mining employment since his last visit to a chest clinic and a chest $x$ ray film is taken.

These data were used in the past to monitor the incidence of silicosis in Ontario miners. When the data were first entered into a computer file, only miners who were employed for at least 60 months in a dusty job in the mines were included because this was assumed to be the minimum exposure time required for the development of silicosis. For men who never mined uranium in Ontario, a minimum of two weeks of employment in dusty jobs in Ontario mines and a minimum of 60 months of employment in dusty jobs anywhere in the mining industry were required for inclusion in the study.

Uranium mines in Ontario were developed more recently and men have been employed in uranium mines for shorter periods than in other Ontario mines. Hence, the employment data for Ontario uranium miners who had worked for at least two weeks in an Ontario uranium mine were added to the computer file.

\section{MORTALITY DATA}

Mortality data for the miners were obtained by searching the mortality database of Statistics Canada for deaths that occurred between 1955 and 1986 . Details about the procedure used to locate the death certificates are given elsewhere. ${ }^{18}$ It has been estimated that $6 \%$ of the deaths that occurred in Ontario miners up to the end of 1977 were not identified by Statistics Canada. ${ }^{1}$ The most frequent reason for this was that the miner died outside Canada.

\section{DEFINITION OF THE STUDY GROUP}

Except for uranium miners, only miners who attended a chest clinic in $\mathbf{1 9 5 5}$ or later and who had been employed for a minimum of two weeks in dusty jobs in mines in Ontario after 1954 and a minimum of 60 months in jobs with dust exposure in mining anywhere were included in the study. Gold miners and men who mined other ores in Ontario were included.

Uranium miners were included if they had attended a chest clinic in 1955 or later, had spent a minimum of two weeks in uranium mines in Ontario, or had been reported to have been exposed to radon decay products by a uranium mining company in Ontario, whether or not they had further exposure in other types of mines. Uranium mining companies in Ontario began to record the exposures of individual miners to radon decay products in 1968. Before 1968, this was estimated from the miner's employment history recorded at the chest clinic and from the annual average concentrations of radon decay products in uranium mines.

Miners who reported that they had worked in an asbestos mine in or outside of Ontario and miners who were known to have mined uranium outside of Ontario were excluded.

\section{GEOLOGICAL CHARACTERISTICS OF ONTARIO GOLD}

MINES

The best known Ontario gold deposits are the "lode gold" ores, where fractures in the host rocks are filled with quartz and contain specks of native gold. The fractures are commonly rimmed with metre wide zones of iron sulphide minerals, mostly pyrite or pyrrhotite, in which gold is also concentrated. The gold has been carried up into the fractures from deeper layers of the earth's crust in dilute watery solutions rich in silica and sulphur. Where temperature and pressure have fallen sufficiently in the ascent, silica has been precipitated and gold, together with sulphur and arsenic, has been deposited by reacting with iron minerals in the wall rocks. These reactions also produce characteristic alteration minerals, some of which are fibrous or flaky, reflecting the composition of the host rock and the crustal level at which they are formed. Pyrite is formed at higher crustal levels; lower in the crust its analogue is pyrrhotite. Arsenic, a well known companion element to gold, ${ }^{9-11}$ is fixed by comparable reactions in the iron arsenic mineral arsenopyrite, or as arsenic rich pyrite. Gold is preferentially concentrated in arsenic bearing minerals ${ }^{1213}$ and a linear correlation exists between the two elements. Moreover, arsenic is unusually abundant in the largest mines of some Ontario gold camps. ${ }^{10}$

Four rock types are the commonest host rocks immediately adjacent to gold ores. Two of these, basalt and its iron-magnesium-chromium rich counterpart komatiite, are volcanic flow rocks with characteristic compositions. The third type, of felsic composition, is a fine grained intrusive igneous member of the granite family. Banded iron formation, which is the fourth common host, is a layered sedimentary rock. Ontario komatiites commonly assay $1000-2000$ ppm chromium..$^{14}{ }^{15}$ Also, they alter readily to serpentine and amphiboles or to flaky minerals such as talc or chlorite.

\section{HISTOLOGY}

Hospitals in which miners with lung cancer were treated were asked to provide blocks, slides, or occasionally cytological specimens in all cases in which a biopsy or necropsy was performed. The diagnoses were confirmed and the carcinomata of the lung were classified according to a modification of the World Health Organisation classification. ${ }^{16}$ 


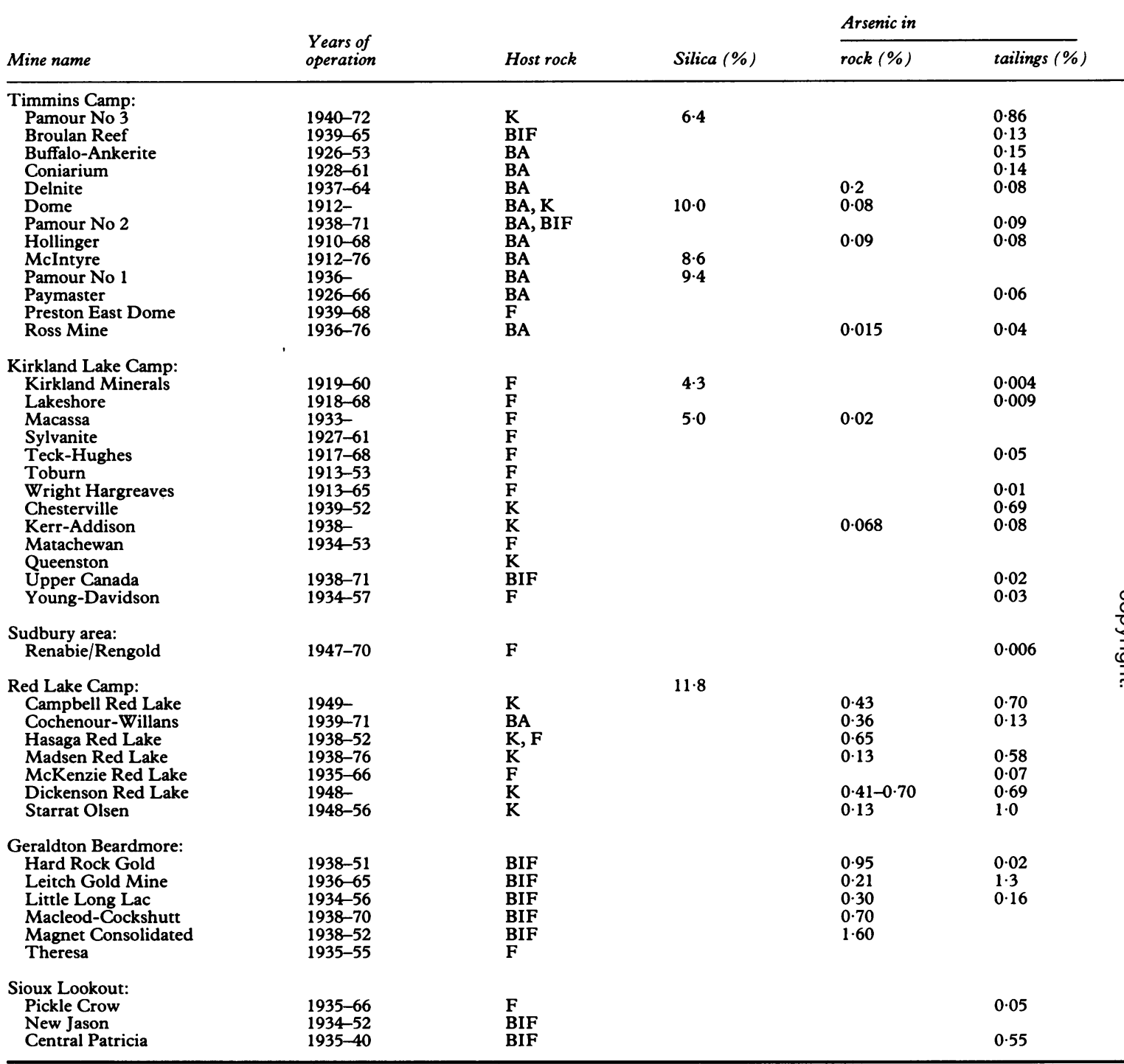

Types of host rock: $\mathbf{B A}=$ basaltic; $\mathbf{B I F}=$ banded iron formation; $\mathbf{F}=$ felsic; $\mathrm{K}=$ komatiitic.

Code for mineral fibre: $\mathrm{t}=$ tremolite; $\mathrm{a}=$ actinolite; fa = fibrous amphibole.

\section{EXPOSURE OF ONTARIO GOLD MINERS}

Dust concentrations

The few dust concentration measurements that were made in gold mines before 1950 and which are still available indicate that dust concentrations for some occupations in the 1930 s and 1940 s were often above 1000 particles $/ \mathrm{ml}(\mathrm{p} / \mathrm{ml})$. Dust concentrations were as low as $500 \mathrm{p} / \mathrm{ml}$ for other occupations in the same mine at the same time. By 1959 the average dust concentration in Ontario gold mines was about 400 $\mathrm{p} / \mathrm{ml}$, and by 1967 the average was under $200 \mathrm{p} / \mathrm{ml}^{17}$ In later years, the variation of dust concentrations between different jobs in the same mine was much less.

Host rock minerals

Published reports were used to establish the rock type, composition, and mineralogy of the rocks immediately adjacent to the gold ore and of the ores themselves. ${ }^{18-22}$ Also, the knowledge of the Provincial 


\begin{tabular}{|c|c|c|c|c|c|c|c|c|}
\hline \multirow{3}{*}{$\begin{array}{l}\text { Months of } \\
\text { dust exposure }\end{array}$} & \multicolumn{6}{|c|}{ Radon decay products (WL) } & \multirow[b]{3}{*}{ Fibre } & \multirow[b]{3}{*}{ Arsenopyrite } \\
\hline & \multicolumn{2}{|c|}{ Inactive } & \multicolumn{2}{|c|}{ Exhaust } & \multicolumn{2}{|c|}{ Active areas } & & \\
\hline & Mean & No & Mean & No & Mean & No & & \\
\hline 88111 & 0.010 & 3 & & & 0.007 & 10 & $\mathrm{t}$ & \\
\hline 26206 & 0.123 & 3 & & & 0.125 & 4 & & \\
\hline \multicolumn{9}{|l|}{$\begin{array}{l}22044 \\
29431\end{array}$} \\
\hline $\begin{array}{l}29431 \\
30921\end{array}$ & & & & & & & $t$ & $x$ \\
\hline 229760 & 0.082 & 5 & 0.055 & 2 & 0.033 & 29 & $t$ & \\
\hline \multicolumn{9}{|l|}{$\begin{array}{r}34491 \\
314715\end{array}$} \\
\hline 260571 & 0.038 & 6 & 0.025 & 4 & 0.041 & 17 & & \\
\hline \multicolumn{9}{|l|}{$\begin{array}{l}95081 \\
38960\end{array}$} \\
\hline \multirow{2}{*}{\multicolumn{9}{|c|}{$\begin{array}{l}59389 \\
23554\end{array}$}} \\
\hline & & & & & & & & \\
\hline \multicolumn{9}{|l|}{37302} \\
\hline 96729 & 0.335 & 2 & 0.192 & 48 & 0.174 & 151 & & \\
\hline \multirow{2}{*}{\multicolumn{9}{|c|}{$\begin{array}{l}42750 \\
49440\end{array}$}} \\
\hline & & & & & & & & \\
\hline \multicolumn{9}{|l|}{$\begin{array}{r}5269 \\
76389\end{array}$} \\
\hline \multirow{2}{*}{\multicolumn{8}{|c|}{183696}} & \\
\hline & 0.001 & & & & 0.003 & 15 & $\mathrm{t}$ & $x$ \\
\hline \multicolumn{9}{|l|}{$\begin{array}{r}6126 \\
452\end{array}$} \\
\hline \multicolumn{9}{|l|}{$\begin{array}{r}51245 \\
8497\end{array}$} \\
\hline \multicolumn{9}{|l|}{12616} \\
\hline 47013 & 0.007 & 6 & 0.006 & 6 & 0.005 & 13 & $t / a$ & $x$ \\
\hline 16973 & 0.020 & 2 & 0.020 & 1 & 0.020 & 1 & & $x$ \\
\hline \multicolumn{9}{|l|}{2624} \\
\hline \multirow{2}{*}{\multicolumn{9}{|c|}{$\begin{array}{r}43161 \\
3045\end{array}$}} \\
\hline & & & & & & & & \\
\hline \multicolumn{9}{|l|}{3641} \\
\hline \multirow{2}{*}{\multicolumn{9}{|c|}{$\begin{array}{r}10764 \\
7418\end{array}$}} \\
\hline & & & & & & & & \\
\hline \multicolumn{9}{|l|}{35515} \\
\hline \multirow{2}{*}{\multicolumn{9}{|c|}{$\begin{array}{r}2328 \\
138\end{array}$}} \\
\hline & & & & & & & & \\
\hline 18364 & & & 0.062 & 5 & & & & \\
\hline $\begin{array}{r}57 \\
16972\end{array}$ & & & & & & & fa & $\begin{array}{l}x \\
x\end{array}$ \\
\hline
\end{tabular}

Resident Geologists and the first hand experience of the staff of the Ontario Geological Survey were utilised to verify and to standardise the information. Current information was needed because older mine records used general field terms that required modern re-evaluation. The geological staff were also asked to record the presence of ultramafic host rock, talcchlorite schists, and one or more of the amphibole species, tremolite, amosite, actinolite, anthophylite, or crocidolite.
Radon decay products

No measurements of the levels of radon decay products in Ontario gold mines were taken before 1961. Beginning in 1961, some measurements of the levels of radon and thoron decay products were made in many Ontario gold mines; most were made in the $1980 \mathrm{~s}$. Table 1 shows the average of measurements in inactive areas, exhaust air, and active areas of the mines. The highest levels of radon decay products were usually found in inactive areas. In some gold 
mines, the average measured levels in inactive areas were 0.3 working levels (WLs) or greater. The levels in other gold mines were below $0.02 \mathrm{WL}$. The levels of radon decay products in inactive areas of gold mines probably represent the maximum to which gold miners were exposed before 1945 when the amount of ventilation in the mines was less than in later years. Hence, the average level of radon decay products in inactive areas of a gold mine was used to estimate the degree of exposure to radon decay products of gold miners who were working in the mine before the end of 1945 . The degree of exposure after 1945 was estimated on the basis of measurements of radon decay products in active work areas that included drifts, stopes, raises, and travelways. For mines that were not included in the survey, exposure estimates were derived from neighbouring gold mines in the same geological setting. These exposure levels and the employment history of each gold miner were used to make estimates of his exposure to radon decay products for each year he was employed in a gold mine in Ontario. Exposure was estimated in terms of working level months (WLMs), a unit that is commonly used to measure exposure to radon decay products.

\begin{abstract}
Arsenic
The arsenic content of major Ontario gold mines and the regional values typical of four geographically distinct gold camps were obtained from summary studies. ${ }^{9-11}$ Also, original wet chemical analytical data from the lithogeochemical database (PETROC) held by the Ontario Geological Survey (OGS) were obtained, together with local lithogeochemical analyses performed by the Geological Survey of Canada. The values confirm the known presence of anomalously high arsenic concentrations where gold is found and show that although arsenic concentrations are raised, particularly in the larger mines, ${ }^{10}$ some camps are more regionally enriched than others. The Red Lake camp is well known for its arsenical ores that make for metallurgical difficulties; the Timmins and Kirkland Lake camps contain more native gold and less arsenic. The residual arsenic content in mine tailings was obtained from the
\end{abstract}

Ontario Ministry of Environment for many individual gold mines.

When the arsenic content of a mine was not known, an estimate was made by extrapolating from the arsenic content of neighbouring mines in the same geological setting. An index of arsenic exposure was calculated for each gold miner for each year that he was employed in a gold mine. This was done by weighting the duration of employment in dusty jobs in Ontario gold mines up to the end of 1945 according to the arsenic content in the mine where he was employed. A second arsenic index was calculated in a similar fashion for each year of employment in gold mines after 1945.

\section{Silica}

A 1978 survey of the amount of airborne respirable dust and silica was used to estimate the percentage of free silica in airborne dust at several major gold mines. Also, a rough estimate of the proportion of silica present as vein material was made from the typical vein pattern seen at different crustal levels. ${ }^{1020}$ Table 1 shows the results.

\section{Smoking}

The smoking habits of randomly selected miners who were born before 1938 were recorded. Either the miner or his next of kin was contacted. Some of the miners in the random sample filled out a question naire and returned it to us by post, some were interviewed on the telephone, and the smoking habits of other miners were found recorded in previous surveys. When the miner or his next of kin were contacted, he or she was asked whether the miner had ever regularly smoked cigarettes, at what age he had started to smoke, when he had stopped, the type of cigarettes smoked, the number of each type of cigarette smoked each day, and whether he smoked pipes or cigars.

\section{STATISTICAL METHODS}

This is a retrospective cohort study of mortality. Men entered the study when they were first reported to have been exposed in an Ontario uranium mine, or when they first attended a chest clinic in 1955, or later,

Table 2 Lung cancer mortality according to ore mined and period of first mining

\begin{tabular}{|c|c|c|c|c|c|c|c|c|c|c|c|c|c|c|c|}
\hline \multirow{3}{*}{$\begin{array}{l}\text { Year of } \\
\text { first gold } \\
\text { mining }\end{array}$} & \multicolumn{14}{|c|}{ Year of first nickel mining } & Nి \\
\hline & \multicolumn{5}{|c|}{ Before 1935} & \multicolumn{5}{|c|}{1935 or later } & \multicolumn{4}{|c|}{ Never } & ס \\
\hline & $O$ & $E$ & $S M I$ & $\mathrm{R}(95 \% C I)$ & $\begin{array}{l}\text { No of } \\
\text { miners }\end{array}$ & $O$ & $E$ & $S M I$ & ( $(95 \% C I)$ & $\begin{array}{l}\text { No of } \\
\text { miners }\end{array}$ & $O$ & $E$ & $S M R$ & $R(95 \% C I)$ & $\underbrace{}_{\infty}$ \\
\hline $\begin{array}{l}\text { Up to } 1945 \\
\text { After } 1945 \\
\text { Never }\end{array}$ & $\begin{array}{r}19 \\
1 \\
53\end{array}$ & $\begin{array}{r}10.49 \\
0.71 \\
37.65\end{array}$ & $\begin{array}{l}181 \\
141 \\
141\end{array}$ & $\begin{array}{r}(109-283) \\
(4-785) \\
(105-184)\end{array}$ & $\begin{array}{r}241 \\
11 \\
728\end{array}$ & $\begin{array}{r}16 \\
8 \\
217\end{array}$ & $\begin{array}{r}13.60 \\
6.23 \\
215.38\end{array}$ & $\begin{array}{l}118 \\
128 \\
101\end{array}$ & $\begin{array}{l}(67-191) \\
(55-253) \\
(88-115)\end{array}$ & $\begin{array}{r}593 \\
741 \\
15892\end{array}$ & $\begin{array}{r}236 \\
98 \\
56\end{array}$ & $\begin{array}{r}168.97 \\
102.93 \\
57.45\end{array}$ & $\begin{array}{r}140 \\
95 \\
97\end{array}$ & $\begin{array}{r}(122-159) \\
(77-116) \\
(74-127)\end{array}$ & $\begin{array}{l}4.84 \\
7892 \\
729 \mathrm{C}\end{array}$ \\
\hline
\end{tabular}


Table 3 Lung cancer mortality of Ontario gold miners up to age 75 according to period of first gold mining and time since first gold mining in Ontario

\begin{tabular}{|c|c|c|c|c|c|c|c|c|c|c|c|c|}
\hline \multirow{2}{*}{$\begin{array}{l}\text { Period of } \\
\text { first gold } \\
\text { mining }\end{array}$} & \multicolumn{4}{|c|}{$\begin{array}{l}\text { Less than } 30 \text { years from first gold } \\
\text { mining }\end{array}$} & \multicolumn{4}{|c|}{$30-39$ years from first gold mining } & \multicolumn{4}{|c|}{40 years or more from first gold mining } \\
\hline & $O$ & $E$ & $S M R$ & $(95 \% C I)$ & $O$ & $E$ & $S M R$ & $(95 \% \mathrm{CI})$ & $O$ & $E$ & $S M R$ & $(95 \% \mathrm{CI})$ \\
\hline $\begin{aligned} &< 1930 \\
& 1930-4 \\
& 1935-9 \\
& 1940-5 \\
& 1946-9 \\
& 1950-4 \\
& 1955-9 \\
& \geqslant 1960\end{aligned}$ & $\begin{array}{r}0 \\
4 \\
8 \\
21 \\
14 \\
20 \\
24 \\
11\end{array}$ & $\begin{array}{r}0.86 \\
4.15 \\
6.78 \\
13.79 \\
12.85 \\
22.01 \\
21.98 \\
12.34\end{array}$ & $\begin{array}{r}0 \\
96 \\
118 \\
152 \\
109 \\
91 \\
109 \\
89\end{array}$ & $\begin{array}{l}(26-247) \\
(51-232) \\
(94-233) \\
(60-183) \\
(56-140) \\
(70-162) \\
(44-159)\end{array}$ & $\begin{array}{r}19 \\
22 \\
24 \\
21 \\
19 \\
12 \\
0 \\
0\end{array}$ & $\begin{array}{r}9 \cdot 35 \\
12 \cdot 24 \\
14 \cdot 31 \\
20 \cdot 83 \\
18 \cdot 60 \\
14 \cdot 49 \\
1 \cdot 31 \\
0\end{array}$ & $\begin{array}{r}203 \\
180 \\
168 \\
101 \\
102 \\
83 \\
0\end{array}$ & $\begin{array}{r}(122-317) \\
(113-277) \\
(107-250) \\
(62-154) \\
(62-160) \\
(43-145)\end{array}$ & $\begin{array}{r}25 \\
29 \\
18 \\
15 \\
1 \\
0 \\
0 \\
0\end{array}$ & $\begin{array}{c}14 \cdot 86 \\
13 \cdot 11 \\
12 \cdot 74 \\
10 \cdot 00 \\
0 \cdot 57 \\
0 \\
0 \\
0\end{array}$ & $\begin{array}{l}168 \\
221 \\
141 \\
150 \\
175\end{array}$ & $\begin{array}{r}(109-248) \\
(148-318) \\
(84-223) \\
(84-247)\end{array}$ \\
\hline
\end{tabular}

and satisfied the definition of the study group, whichever occurred first. Person-years at risk were counted from the year of entry to the study up to the year when the miner began uranium mining in Ontario, the year of death, or the end of the period of observation for mortality, whichever occurred first.

The mortalities of Ontario men were used to calculate the expected numbers of deaths. The statistical significance of the difference between the observed and expected numbers of deaths was determined using the Poisson probability distribution. Poisson regression was used to determine how several factors jointly affected the cancer mortality. ${ }^{23}$

\section{Results}

\section{MORTALITY RATES}

The study population of 54128 miners was at risk of dying for a total of 1076103 years. A total of 9690 deaths were observed in the study population and 10397.9 were expected. Over the age of 75 , mortality from all causes combined was much lower than expected, especially among foreign born miners. This was probably due to deaths outside Canada, which are not always recorded in the Canadian mortality database.

The men who entered the study as non-uranium miners were classified according to the calendar period when they began nickel mining and gold mining. Table 2 shows the numbers of men in each category. Of the 37493 men who entered the study as non-uranium miners, 6260, including 2869 gold miners went on to become uranium miners. Table 2 also shows the relation between lung cancer mortality and the period when miners in the study started mining gold or nickel in Ontario. Mortality that occurred after the miner began to work in a uranium mine is excluded. A statistically significant excess of mortality from lung cancer was found among miners who started gold mining before 1946 and never mined nickel (standard mortality ratio (SMR) 140, $95 \%$ confidence interval $(95 \% \mathrm{CI}) 122-159)$ and in miners who started nickel mining before 1936 and never mined gold (SMR 141, 95\% CI 105-184). The lung cancer mortalities among men who both mined gold before 1946 and nickel before 1936 were also increased (SMR 181, 95\% CI 109-283). No increase in lung cancer mortality was detected in miners who began mining gold after 1945 and never mined nickel (SMR 95, 95\% CI 77-116) and no increase in lung cancer mortality was detected in miners who began nickel mining after 1935 and did not mine gold (SMR $101,95 \%$ CI 88-115). The death rates from lung cancer in miners who mined ore other than gold and nickel were not increased (SMR 97, 95\% CI 74-127).

Table 3 shows lung cancer mortality up to the age of 75 in relation to the period when gold miners began mining gold and to the interval between the time when the miners began mining gold and the time when death due to lung cancer occurred. Lung cancer mortality was increased for gold miners who began mining gold before 1940 and survived for 30 or more years after beginning gold mining in Ontario. A borderline statistically significant excess of lung cancer was found among miners who began gold mining between 1940 and 1945 (SMR 128, 95\% CI 97-166). An excess of lung cancer mortality was not detected among miners who began mining gold after 1945 , even in those who survived more than 30 years after beginning gold mining.

\section{HISTOLOGY}

Tissue from 122 of the 378 carcinomata of the lung in gold miners was available for review. Table 4 shows that the distribution of the different types of carcinoma was similar to that in the 3514 cases of four

Table 4 Histology of tumours of Ontario gold miners in comparison with control series

\begin{tabular}{|c|c|c|c|}
\hline \multirow[b]{2}{*}{ Cell type } & \multicolumn{2}{|c|}{ Gold miners } & \multirow{2}{*}{$\begin{array}{l}\text { Control } \\
\text { series }(\%)\end{array}$} \\
\hline & No $(\%)$ & Mean age (y) & \\
\hline $\begin{array}{l}\text { Squamous } \\
\text { Adenocarcinoma } \\
\text { Large cell } \\
\text { Neuroendocrine }\end{array}$ & $\begin{array}{l}35(32) \\
31(28) \\
13(12) \\
30(28)\end{array}$ & $\begin{array}{l}64 \\
64 \\
62 \\
62\end{array}$ & $\begin{array}{r}25-41 \\
17-44 \\
7-17 \\
15-23\end{array}$ \\
\hline
\end{tabular}


Table 5 Lung cancer mortality in gold miners and exposure to arsenic, exposure to radon decay products, and duration of employment in gold mines with mineral fibre

\begin{tabular}{|c|c|c|}
\hline & Obs & $\operatorname{Exp}(S M R)$ \\
\hline \multicolumn{3}{|c|}{ Exposure to arsenic before 1946 lagged by 20 years } \\
\hline $\begin{array}{c}\text { Mean inc } \\
0.00 \\
0.05 \\
0.20 \\
0.59 \\
1.56 \\
5.76\end{array}$ & $\begin{array}{c}\text { arsen } \\
106 \\
21 \\
43 \\
75 \\
47 \\
15\end{array}$ & $\begin{array}{rr}\text { As-y): } & \\
107.9 & (98) \\
21 \cdot 2 \quad(99) \\
29 \cdot 4(146) \\
44 \cdot 1(170) \\
28 \cdot 8(163) \\
6 \cdot 0(252)\end{array}$ \\
\hline \multicolumn{3}{|c|}{ Exposure to arsenic after 1945 lagged by 20 years } \\
\hline $\begin{array}{c}\text { Mean inc } \\
0.00 \\
0.05 \\
0.19 \\
0.60 \\
3.00\end{array}$ & $\begin{array}{c}\text { arsen } \\
78 \\
34 \\
43 \\
99 \\
53\end{array}$ & $\begin{array}{l}\text { As-y): } \\
62 \cdot 6(125) \\
27 \cdot 1(126) \\
37 \cdot 1(116) \\
65 \cdot 3(152) \\
45 \cdot 3(117)\end{array}$ \\
\hline \multicolumn{3}{|c|}{ Exposure to radon decay products lagged by five years } \\
\hline $\begin{array}{c}\text { Mean ex } \\
0 \\
2 \\
9 \\
23 \\
67\end{array}$ & $\begin{array}{c}\text { ecay pr } \\
2 \\
113 \\
113 \\
62 \\
17\end{array}$ & $\begin{array}{r}1.5(130) \\
106 \cdot 4(106) \\
83.0(136) \\
36 \cdot 4(171) \\
10 \cdot 1(168)\end{array}$ \\
\hline Duration & $\begin{array}{l}\text { gold } m \\
\text { by } 20\end{array}$ & neral fibre lagge \\
\hline $\begin{array}{c}\text { Mean du } \\
0 \\
6 \\
19\end{array}$ & $\begin{array}{c}\text { nent }(y \\
230 \\
71 \\
6\end{array}$ & $\begin{array}{r}172 \cdot 7(133) \\
59 \cdot 6(119) \\
5 \cdot 2(116)\end{array}$ \\
\hline
\end{tabular}

series of patients reported previously, ${ }^{24-27}$ except that the proportion of neuroendocrine (oat cell) tumours was slightly increased. In all the published cases, the histological slides had been reviewed and the tumours reclassified by modern criteria.

Hospital records indicated three cases of mesothelioma among the miners; two of these cases occurred among men who had worked in the gold mines. One of the gold miners had worked for 13 months in a small mine in the Timmins camp and for 245 months in a mine in which the host rock was felsic. The other had worked for 26 months in a mine with basaltic host rock, four months in a mine outside Ontario, and 26 months in a small mine in the Timmins camp. Neither gold miner was known to be exposed to the komatiite rocks that sometimes contain fibrous amphiboles.

\section{LUNG CANCER MORTALITY AND EXPOSURE TO RADON} DECAY PRODUCTS, MINERAL FIBRE, AND ARSENIC

Lung cancer deaths among gold miners who had not mined nickel before 1936 were categorised according to degree of exposure to radon decay products in gold mines lagged by five years, the indices of exposure to arsenic before 1945 and after 1945 each lagged by 20 years, and the duration of employment in mines containing mineral fibre lagged by 20 years. The duration of employment in gold mines containing mineral fibre lagged by 20 years was classified as 0 years, between 0 and 10 years, and 10 years or more. The observed and expected numbers of deaths from lung cancer in each category were calculated.

Table 5 shows lung cancer mortality in relation to each type of exposure. Poisson regression analysis of these data indicated a statistically significant linear increase in lung cancer mortality as the index of arsenic exposure up to the end of 1945 lagged by 20 years increased $\left(\chi^{2}\right.$ on one degree of freedom 14.9, $\mathrm{p}=0.0001)$ and a significant linear increase in the relative risk of lung cancer as exposure to radon decay products lagged by five years increased $\left(\chi^{2} 6 \cdot 6, p=\right.$ $0 \cdot 01)$. No association between lung cancer mortality and the index of exposure to arsenic in gold mines after 1945 lagged by 20 years was detected $\left(\chi^{2} 0 \cdot 2\right.$, $\mathrm{p}=0 \cdot 6)$; nor was an association found between lung cancer mortality and exposure to mineral fibre in gold mines $\left(\chi^{2} 0 \cdot 6, \mathrm{p}=0.5\right)$.

The joint effect of exposure to radon decay products in gold mines and the index of exposure to arsenic in gold mines up to the end of 1945 was estimated. The index of exposure to arsenic was lagged by $15,20,25$, and 30 years. Although a statistically significant association between exposure to arsenic before 1946 and lung cancer mortality was found for each lag interval, the best fit was found for a 8 lag interval of 20 years. The equation of the best fitting regression line was

$$
\mathrm{O} / \mathrm{E}=1.02+0.31 \mathrm{As}+0.012 \mathrm{WLM}
$$

where $\mathrm{O}=$ observed number of lung cancer cases; $\mathrm{E}=$ expected number of lung cancer cases; WLM = estimated exposure to radon decay products in Ontario gold mines lagged by five years; As = index of exposure to arsenic in Ontario gold mines up to the end of 1945 lagged by 20 years.

The regression coefficient for the arsenic index differed significantly from zero $\left(\chi^{2} 11 \cdot 7, p=0.0006\right)$ as did the coefficient of the estimated exposure to

Table 6 Lung cancer mortality and years worked and exposure to arsenic up to the end of 1945 and exposure to radon decay products

\begin{tabular}{lll}
\hline & & $\begin{array}{l}\text { Degrees } \\
\text { of } \\
\text { freedom }\end{array}$ \\
\hline $\mathrm{O} / \mathrm{E}=1.29$ & Deviance & $\begin{array}{l}\text { fred } \\
\mathrm{O} / \mathrm{E}=1.01+0.066 \mathrm{y}\end{array}$ \\
$\mathrm{O} / \mathrm{E}=1.13+0.016 \mathrm{WLM}$ & 84.5 & 72 \\
$\mathrm{O} / \mathrm{E}=1.13+0.34 \mathrm{As}$ & 63.1 & 71 \\
$\mathrm{O} / \mathrm{E}=1.02+0.012 \mathrm{WLM}+0.31 \mathrm{As}$ & 70.8 & 71 \\
$\mathrm{O} / \mathrm{E}=1.00+0.05 \mathrm{y}+0.0005$ WLM & 66.1 & 70 \\
$+0.14 \mathrm{As}$ & $61 \cdot 1$ & 69 \\
$\mathrm{O} / \mathrm{E}=1.00+0.05 \mathrm{y}+0.13$ As & 61.1 & 70 \\
$\mathrm{O} / \mathrm{E}=1.02+0.07 \mathrm{y}-0.003 \mathrm{WLM}$ & 63.0 & 70 \\
\hline
\end{tabular}

$\mathrm{O}=$ Observed number of lung cancer cases; $\mathrm{E}=$ expected number of lung cancer cases; $y=$ years of exposure to dust up to 1945 , lagged 20 years; As $=$ index of exposure to arsenic up to end of 1945 lagged 20 years; WLM = working level months of exposure lagged five years. 
Table 7 Survey of smoking habits of miners

\begin{tabular}{|c|c|c|c|c|c|c|c|c|}
\hline \multirow[b]{2}{*}{$\begin{array}{l}\text { Year of } \\
\text { birth }\end{array}$} & \multicolumn{2}{|c|}{ Gold before 1945} & \multicolumn{2}{|c|}{ Gold after 1945} & \multicolumn{2}{|l|}{ Nickel } & \multicolumn{2}{|c|}{ Both gold and nickel } \\
\hline & $\begin{array}{l}\text { No of } \\
\text { miners }\end{array}$ & $\%$ Smokers & $\begin{array}{l}\text { No of } \\
\text { miners }\end{array}$ & $\%$ Smokers & $\begin{array}{l}\text { No of } \\
\text { miners }\end{array}$ & $\%$ Smokers & $\begin{array}{l}\text { No of } \\
\text { miners }\end{array}$ & $\%$ Smokers \\
\hline $\begin{array}{l}<1910 \\
1910-19 \\
1920-29 \\
1930-37\end{array}$ & $\begin{array}{r}86 \\
55 \\
19 \\
1\end{array}$ & $\begin{array}{r}76 \\
84 \\
95 \\
0\end{array}$ & $\begin{array}{l}13 \\
41 \\
81 \\
55\end{array}$ & $\begin{array}{l}62 \\
73 \\
85 \\
76\end{array}$ & $\begin{array}{r}10 \\
101 \\
178 \\
108\end{array}$ & $\begin{array}{l}70 \\
80 \\
90 \\
86\end{array}$ & $\begin{array}{r}2 \\
15 \\
13 \\
10\end{array}$ & $\begin{array}{l}50 \\
73 \\
85 \\
50\end{array}$ \\
\hline
\end{tabular}

radon decay products $\left(\chi^{2} 4 \cdot 7, p=0.03\right)$. A further term representing the interaction of exposure to radon decay products and arsenic was not statistically significant and the risk from exposure to radon decay products or arsenic did not depend on attained age.

\section{LUNG CANCER MORTALITY AND DURATION OF}

EMPLOYMENT BEFORE 1945

Lung cancer mortality was associated with duration of employment in gold mines up to the end of 1945 $\left(\chi^{2} 21 \cdot 4, p=4 \times 10^{-6}\right)$. Table 6 shows a series of models relating lung cancer mortality to exposure to arsenic and radon decay products and to duration of employment in gold mines up to the end of 1945 . These models indicate that each year of employment up to the end of 1945 in gold mines in Ontario was associated with increased lung cancer mortality 20 or more years after employment began. They also indicate, on the basis of the fit of the data to the model only, that the model that relates lung cancer mortality to the duration of employment in gold mines up to the end of 1945 is to be preferred to the model that relates lung cancer mortality to exposure to arsenic and radon decay products.

\section{SMOKING HABITS OF MINERS}

Table 7 shows the estimated proportion of smokers in relation to year of birth and ore mined. Of the 1414 miners in the random sample, smoking habits were obtained for 1189; of these 161 were gold miners who began mining gold up to the end of 1945, 190 were gold miners who began mining gold after 1945, 397 were nickel miners, and 40 mined both nickel and gold. The other miners in the survey were either uranium miners or miners who mined neither gold nor nickel. All but one of the nickel miners in the survey began mining nickel after 1935. A logistic regression analysis of these data indicated that miners who were born more recently were more likely to be smokers $\left(\chi^{2} 15.47\right.$ on 3 degrees of freedom, $p=0.002)$. The smoking habits of miners who began mining gold before 1945 and of nickel miners did not differ significantly $\left(\chi^{2} 0.001\right.$ on one degree of freedom, $p=0.98$ ). Miners who began mining gold after 1945 were less likely to be smokers than nickel miners and other gold miners $\left(\chi^{2} 4.6\right.$ on one degree of freedom, $p=0.03$ ).

\section{Discussion}

\section{SMOKING}

Smoking is an unlikely explanation of the excess of lung cancer mortality among Ontario gold miners. A comparison of gold miners who started mining gold up to the end of 1945 and of nickel miners who began mining nickel after 1935 could not show that the gold miners were more likely to be smokers. A previous study $^{2}$ showed that after taking smoking into account, a statistically significant association existed between lung cancer and duration of exposure to high concentrations of dust in the gold mines.

\section{EXPOSURE TO RADON PROGENY IN GOLD MINES}

Lung cancer mortalities of uranium miners are increased because of their exposure to radon decay products. ${ }^{3}$ The estimates of the degree of exposure to radon decay products in Ontario gold mines are based on measurements which were extrapolated from one mine to another and which were extrapolated 40 years or more back in time. Nevertheless, the estimated increase in lung cancer mortality in terms of accumulated exposure to radon decay products is consistent with current estimates based on data from uranium miners. The estimated exposure to radon decay products in Ontario gold mines resulted in some gold miners accumulating exposures in excess of 50 WLM. The estimated exposure to radon decay products for most Ontario gold miners, however, was not sufficiently high to be alone responsible for the excess mortality from lung cancer.

\section{EXPOSURE TO ARSENIC}

Exposure to arsenic is suspected to be the cause of the increased lung cancer mortality in gold miners in France ${ }^{4}$ and radon decay products and arsenic are the suspected causes of the increased incidence of lung cancer in tin miners in Yunnan Province, China. ${ }^{5}$ An excess of lung cancer also exists among gold miners in Western Australia where the arsenic concentrations in the rocks mined range up to $0.03 \%$ though the average concentration is less than $0.005 \%$ and where the level of radon decay products are at most 0.045 WL. ${ }^{28}$

The exposure to arsenic was measured in our study in terms of the duration of employment and the 
estimated amount of arsenic in the rocks that the miners worked with. A more appropriate measure of exposure would be the amount of arsenic in airborne respirable dust to which miners were exposed during the 1930s and 1940s but no such measurements are available. Despite the limitations of the data, they indicate that most of the increase in the lung cancer mortality is associated with exposure to arsenic in Ontario gold mines.

The analysis of the joint effect of exposure to radon decay products and arsenic showed that each exposure appears to act independently upon risk of lung cancer so that the risk to a miner exposed to both arsenic and radon decay products is the sum of the risks from each exposure. The difference between an additive and a multiplicative model, however, is not large enough to be detected in this study.

\section{EXPOSURE TO MINERAL FIBRE}

Miners exposed to asbestiform fibrous mineral have increased mortalities for lung cancer and mesothelioma. ${ }^{29}{ }^{30}$ This type of exposure is unlikely to be important in Ontario gold miners. Fibrous minerals are found in the komatiite rocks present in some Ontario gold mines, but no excess of carcinoma of the lung was associated with the duration of employment in mines containing mineral fibre. Also, if asbestiform fibre were a major factor in causing the increased incidence of lung carcinoma, one would have expected a higher incidence of mesothelioma in the miners.

\section{EXPOSURE TO SILICA}

Several recent studies have shown an excess of lung cancer in miners and others with silicosis, and have suggested that quartz may be a carcinogen in the lung. ${ }^{6}$ Others doubt that this is the case. ${ }^{31} 32$

The data on the amount of silica in Ontario gold mines indicate that all Ontario gold miners working before 1945 were exposed to similar amounts of silica. If this were the case, duration of exposure to dust up to the end of 1945 would be a good surrogate for exposure to silica. The calculations presented here show that the model relating cancer mortality to exposure to dust is to be preferred to the model relating cancer mortality to exposure to radon decay products and arsenic, an observation compatible with the hypothesis that exposure to silica was a factor in the causation of the excess of lung cancer. The presence in the atmosphere of the mine of two known lung carcinogens, radon decay products and arsenic, however, and the model showing a dose related association between exposure to these carcinogens and lung cancer mortality make it much more probable that the excess of lung cancer is due to exposure to radon decay products and arsenic.

\section{NICKEL MINERS}

The mortalities shown here indicate that miners who started mining nickel in Ontario before 1935 had increased mortality from lung cancer that was not the result either of working in the uranium mines in or outside of Ontario or of working in the gold mines in Ontario. An excess of lung cancer in miners first employed before 1930 by one large nickel mining company in Ontario has also been shown ${ }^{33}$; some of the miners included in that study group are probably included in our study group.

\section{Conclusion}

We conclude that the incidence of carcinoma of the lung is increased in Ontario miners who began to mine gold before the end of 1945 or nickel before the end of 1935. No excess of lung cancer could be detected in miners who began mining gold after 1945 or nickel after 1935. This increased incidence of lung cancer in Ontario gold miners is probably due to exposure to arsenic and radon decay products.

The Ontario Ministry of Labour, the Workers' Compensation Board of Ontario, and the Atomic Energy Control Board provided the funds for this study.

Ms Irene Rule was indispensable in keeping track of the data. Ms Rose Pagliaro assisted in data entry and Ms C Petit did numerous translations to and from French and English. Mr Colin Benjamin and Ms Elizabeth Grosselfeuger coordinated the reviewe of the tissue samples. Dr Walker of Sudbury? Memorial Hospital provided detailed information about the smoking habits and employment histories of many lung cancer and stomach cancer patients.

Cooperation in locating hospital records was provided by the Ontario Cancer Treatment and Research Foundation, the British Columbia Cancer Control Agency, Alberta Cancer Agency, the Saskatchewan Cancer Foundation, Manitoba Cancer Treatment and Research Foundation, Ministère de la Santé et des Services Sociaux du Québec, New Brunswick Tumour Registry, and the Cancer Treatment and Research Foundation of Novia Scotia. Many hospitals in Canada provided copies of patient records and tissue samples.

1 Muller J, Wheeler WC, Gentleman JF, Suranyi G, Kusiak RA. Study of Ontario miners, 1955-1977, part 1. Ontario: Ontario Ministry of Labour, Ontario Workers' Compensation Board, Atomic Energy Control Board. 1983.

2 Muller J, Kusiak RA, Suranyi G, Ritchie AC. Study of mortality of Ontario gold miners 1955-1977. Ontario: Ontario Ministry of Labour, Ontario Workers' Compensation Board, Atomic Energy Control Board. 1986.

3 Committee on the biological effects of ionizing radiation (BEIR IV). Health risks of radon and other alpha emitters. Washington: National Academy Press, 1988.

4 International Agency for Research on Cancer. A Mortality study of miners and factory workers at the 'societe des mines et produits chimiques de salsigne' Lyon: IARC; World Health Organization, 1989.

5 Taylor PR, Qiao Y-L, Schatzkin A, Yao S-X, Lubin J, Mao B-L, et al. Relation of arsenic exposure to lung cancer among tin 
miners in Yunnan Province, China. Br J Ind Med 1989; 46:881-6.

6 Goldsmith DF, Guidotti TL, Johnston DR. Does occupationa exposure to silica cause lung cancer? Am J Ind Med 1982; 3:423-40.

7 Ontario Ministry of Environment. Arsenic in mining waste. Internal report. Toronto: (unpublished) 1986.

8 Smith ME, Newcombe HB. Automated follow-up facilities in Canada for monitoring delayed health effects. Am J Publ Health 1980;70:1261-8.

9 Fyon JA, Crocket JH. Gold exploration in the Timmins area using field and lithogeochemical characteristics of carbonate zones. Ontario: Ontario Geological Survey Study, 1983. (No 26.)

10 Hodgson CJ. Preliminary report on a computer file of gold deposits of the Abitibi Belt, Ontario. In: Colvine AC, ed. The geology of gold in Ontario. Ontario: Ontario Geological Survey, 1983:11-37. Miscellaneous paper 110.

11 Durocher ME. The nature of hydrothermal alteration associated with the Madsen and Starrat-Olsen gold deposits, Red Lake Area. In: Colvine AC, ed. The geology of gold in Ontario. Ontario: Ontario Geological Survey, 1983:123-40. Miscellaneous paper 110

12 Cook NJ, Chryssoulis SL. Concentrations of 'invisible gold' in the common sulphides. Canadian Mineralogist 1990;28:1-16.

13 Springer J. Invisible gold. In: Colvine AC, ed. The geology of gold in Ontario. Ontario: Ontario Geological Survey, 1983:240-50. (Miscellaneous paper 110.)

14 Condie KC. Archean greenstone belts. Amsterdam: Elsevier, 1981.

15 Wilson HDB, Morrice MG. The volcanic sequence in archean shields. In: Baragar WRA, Coleman LC, Hall JM, eds. Volcanic regimes in Canada. Waterloo, Ontario: Geological Association of Canada, 1977. (Special paper 16.)

16 World Health Organization. International classification of diseases, vol 1. Geneva: WHO, 1977.

17 Mines Accident Prevention Association of Ontario. Thirtyseventh annual report. North Bay, Ontario: MAPAO, 1968.

18 Structural geology of Canadian ore deposits: a symposium. Canadian Institute of Mining and Mineralogy. Montreal, Quebec: 1948;1-645.

19 Ferguson SA, Groen HA, Haynes R. Gold deposits of Ontario, Part 1. Districts of Algoma, Cochrane, Kenora, Rainy River and Thunder Bay. Ontario: Ontario Department of Mines, Mineral Resources. Ministry of Northern Development and Mines. 1971. (Circular No 13.)
20 Colvine AC, Fyon JA, Heather KB, Marmont S, Smith PM, Troop DG. Archean lode gold deposits in Ontario. Ontario: Ontario Geological Survey, 1988. (Miscellaneous paper 139.)

21 Colvine AC, Andrews AJ, Cherry ME, Durocher ME, Fyon AJ, Lavigne MJ Jr, et al. An integrated model for the origin of archean lode gold deposits. Ontario: Ontario Geological Survey, 1984. (Open file report 5524.)

22 Colvine AC, ed. The geology of gold in Ontario. Ontario: Ontario Geological Survey, 1983. Miscellaneous paper 110.

23 Frome EL. The analysis of rates using poisson regression models. Biometrics 1983;39:665-74.

24 Beard CM, Jedd MB, Woolner LB, Richardson RL, Bergstrahl EJ, Melton LJ. III. Fifty-year trend in incidence rates of bronchogenic carcinoma by cell types in Olmstead County, Minnesota. J Natl Cancer Inst 1988;80:1404-7.

25 Cox JD, Yesner RA. Adenocarcinoma of the lung. Am Rev Respr Dis 1979;120:1025-9.

26 Valaitis J, Warren S, Gamble D. Increasing incidence of adenocarcinoma of the lung. Cancer 1981;47:1042-6.

27 Vincent RG, Pickren JW, Lane WW, Bross I, Takita H, Houten $\mathrm{L}$, et al. The changing histopathology of lung cancer. Cancer 1977;39:1647-55:

$28^{\circ}$ Armstrong BK, McNulty JC, Levitt LJ, Williams KA, Hobbs MST. Mortality in gold and coal miners in Western Australia with special reference to lung cancer. Br J Ind Med 1979; 36:199-205.

29 Amandus $\mathrm{HE}$, Wheeler $\mathrm{R}$. The morbidity and mortality of vermiculite miners and millers exposed to tremolite-actinolite: part 2. Mortality. Am J Ind Med 1987;11:15-26.

30 De Klerk NH, Armstrong BK, Musk AW, Hobbs MST. Cancer mortality in relation to measures of occupational exposure to crocidolite at Wittenoom Gorge in Western Australia. Br J Ind Med 1989;46:529-36.

31 McDonald JC. Silica, silicosis and cancer. Br J Ind Med 1989; 46:289-291.

32 Hepplestone AG. Silicosis, pneumoconiosis and carcinoma of the lung. Am $J$ Ind Med 1985;7:285-94.

33 Roberts RS, Julian JA, Muir DCF, Shannon HS. A study of mortality in workers engaged in the mining, smelting, and refining of nickel. II Mortality from cancer of the respiratory tract and kidney. Toxicol Ind Health 1989;5:975-93.

Accepted 8 April 1991 